\title{
ARAŞTIRMA / RESEARCH \\ Üreazın modifiye edilmiş florisile kovalent immobilizasyonu ve serbest ve immobilize üreazın karakterizasyonu
}

Covalent immobilization of urease onto modified florisil and characterization of free and immobilized urease

Özlem Alptekin iD

Çukurova Üniversitesi, Eczacılık Fakültesi, Temel Eczacılık Bilimleri Bölümü, Biyokimya Anabilim Dalı, Adana, Turkey

Cukurova Medical Journal 2019;44(3):811-818.

\section{Abstract}

Purpose: In this study, it was aimed to immobilize urease from Canavalia ensiformis onto modified Florisil (magnesium silicate) by covalently and to characterize immobilized urease and also to investigate reusability of immobilized urease in a batch type bioreactor.

Materials and Methods: Florisil was activated with 3aminopropyltriethoxysilane and then modified with glutaraldehyde. Urease was covalently immobilized onto modified support. Images of support and immobilized urease were examined on a scanning electron microscope. The optimum $\mathrm{pH}$ and temperature, kinetic parameters $\left(K_{\mathrm{m}}, V_{\max }, k_{\text {cat }} / K_{\mathrm{m}}\right)$ and storage stabilities at $4^{\circ} \mathrm{C}$ and room temperature of free and immobilized ureases were determined. Reusability of immobilized urease was investigated in a batch type bioreactor.

Results: Free and immobilized ureases showed their maximum activities at $\mathrm{pHs} 7.0$ and 6.5 , and at temperatures 50 and $60^{\circ} \mathrm{C}$, respectively. The $K_{\mathrm{m}}$ value of immobilized urease increased 2.2 fold compared to free urease. The catalytic efficiency of immobilized urease was about $0.1 \%$ of the free urease. Free urease completely lost its activity at the end of 5 days stored at $4^{\circ} \mathrm{C}$ and room temperature; however, immobilized urease did not lose its activity at the end of 19 days at the same conditions. Immobilized urease maintained $50 \%$ of its initial activity at the end of 10 reuses in batch type bioreactor.

Conclusions: Although urease activity significantly decreased upon covalent immobilization onto modified Florisil. However, high storage stability and reusability of immobilized urease makes it potentially useful immobilized form.

Keywords: Urease, immobilization, bioreactor, florisil
Öz

Amaç: Bu çalıșmada, Canavalia ensiformis kaynaklı üreazın modifiye edilmiş Florisil'e (magnezyum silikat) kovalent immobilize edilmesi ve immobilize üreazın karakterizasyonunun yapılarak biyoreaktör uygulamalarında kullanılabilirliğinin araştırılması amaçlanmıştır.

Gereç ve Yöntem: Florisil, 3-aminopropiltrietoksisilan ile aktifleştirilmiş daha sonra glutaraldehit ile modifiye edilmiştir. Modifiye edilmiş desteğe üreazın kovalent immobilizasyonu gerçekleştirilmiştir. Desteğin ve immobilize üreazın taramalı elektron mikroskobunda görüntüleri incelenmiștir. Serbest ve immobilize üreazın optimum pH's1, optimum sıcaklığ1, kinetik parametreleri $\left(K_{\mathrm{m}}, V_{\max }, \quad k_{\text {cat }} / K_{\mathrm{m}}\right)$ belirlenmiș ve $4^{\circ} \mathrm{C}$ 'de ve oda sıcaklığında depolama kararlılıkları incelenmiştir. İmmobilize üreazın tekrar kullanım kararlılığ1 kesikli tip reaktörde araştırilmıştır.

Bulgular: Serbest ve immobilize üreaz için optimum $\mathrm{pH}$ sirasiyla 7,0 ve 6,5 ; optimum sicaklik ise 50 ve $60^{\circ} \mathrm{C}$ olarak belirlenmiștir. İmmobilizasyondan sonra enzimin $K_{\mathrm{m}}$ değeri 2,2 kat artmıştır. İmmobilize üreazın katalitik etkinliği, serbest üreazın katalitik etkinliğinin \%0,1'i kadar bulunmuștur. Oda sicaklığında ve $4^{\circ} \mathrm{C}$ 'de serbest üreaz 5 gün sonunda aktivitesini tamamen kaybederken, ayn koşullarda immobilize üreaz 12 gün sonunda aktivitesini kaybetmemiştir. İmmobilize üreaz kesikli tip biyoreaktörde 10 kullanım sonunda başlangıç aktivitesinin \%50'sini korumuştur.

Sonuç: İmmobilize üreaz, serbest üreaza göre düşük aktivite göstermekle beraber, depolama kararlıllğının ve biyoreaktör uygulamalarında tekrar kullanımının yüksek olması immobilize üreazın serbest üreaza göre kullanım potansiyelini arttırmaktadır.

Anahtar kelimeler: Üreaz, immobilizasyon, biyoreaktör, florisil

Yazışma Adresi/Address for Correspondence: Dr. Özlem Alptekin, Cukurova Üniversitesi, Eczacıllk Fakültesi, Temel Eczacllık Bilimleri Bölümü, Biyokimya Anabilim Dalı, Adana, Turkey e-mail: oalptekin@cu.edu.tr

Geliş tarihi/Received: 16.08.2018 Kabul tarihi/Accepted: 06.01.2019 Çevrimiçi yayın/Published online: 24.02.2019 


\section{GİRİŞ}

Üreaz (EC 3.5.1.5), ürenin amonyak ve karbondioksite dönüşümünü katalizleyen bir enzimdir.

$$
\left(\mathrm{NH}_{2}\right)_{2} \mathrm{CO}+\mathrm{H}_{2} \mathrm{O} \rightarrow \mathrm{CO}_{2}+2 \mathrm{NH}_{3}
$$

Birçok bitki, bakteri, mantar ve alg de bulunan enzim, azotun doğadaki genel metabolizmasında önemli bir rol oynar ${ }^{1}$. Canavalia ensiformis kaynaklı üreaz enzimi, $91 \mathrm{kDa}$ molekül ağırlı̆̆ına sahip birbirinin aynı alt birimleri içeren bir hekzamerdir. Toplam molekül ağırlı̆̆1 $590 \mathrm{kDa}$ olup, $12 \mathrm{~nm}$ boyutundadır ${ }^{2}$. Enzimin aktif merkezinde aktivitesinde çok önemli rol oynayan iki nikel iyonu bulunur ${ }^{3}$

İmmobilize enzim kullanımı, reaksiyon koşullarının kolay kontrol edilebilmesi, reaksiyon ortamindan kolayca uzaklaştırılabilmesi ve tekrar kullanılabilirliği gibi nedenlerle serbest enzim kullanımına göre üstünlükler sağlamaktadır ${ }^{4}$. İmmobilize üreaz, sağllk alanında diagnostik amaçlı biyosensörlerde, ürenin kandan uzaklaştırılmasında ya da hemodiyaliz işleminde sentetik diyalizat çözeltisinin yenilenmesinde kullanılmaktadır. Ayrıca gıda endüstrisinde içeceklerden ürenin uzaklaştırılmasında ve gübre atık sularında bulunan ürenin dönüştürülmesinde de kullanım alanına sahiptir ${ }^{5-9}$. Son yillarda üreazın kovalent immobilizasyonunda aktif karbon, katyonik lâteks partiküller, cyrogel, $\mathrm{TiO}_{2}$ boncuklar, yumurta kabuğu zarı, magnetik nanopartiküller ve altınglutatyon nanokonjügat, selüloz gibi destekler kullanılmıştır ${ }^{5-12}$. İnorganik destekler termal ve mekanik kararlılıklarının yüksek olması ve toksik olmamaları nedeniyle immobilizasyon çalışmalarında s1klıkla tercih edilmektedir ${ }^{4}$. Florisil (magnezyum silikat), $\% 15 \mathrm{MgO}$ ve $\% 85 \mathrm{SiO}_{2}$ içeren, gözenek büyüklüğ̈ 6-8 nm, spesifik yüzey alanı ise 170-300 $\mathrm{m}^{2} /$ g'dır. Ayrıca termal kararlılı̆̆ı yüksek, hidrofilik karakterde, mikrobiyal saldirılara ve organik çözücülere karşı dayanıklı bir destektir ${ }^{13}$.

$\mathrm{Bu}$ çalışmada, Florisil destek 3aminopropiltrietoksisilan (3-APTES) ile aktifleştirildi ve glutaraldehit ile modifiye edildi. Desteğin modifikasyonundan sonra üreaz kovalent olarak desteğe bağlandı. İmmobilize üreazın optimum pH's1, sicaklığı, kinetik parametreleri $\left(K_{m}, V_{\max }\right.$, $\mathrm{k}_{\mathrm{cat}} / \mathrm{K}_{\mathrm{m}}$ ) belirlenerek, depolama kararlılığ1 ve kesikli tip biyoreaktörde tekrar kullanım kararlılığ araștırıldı.

\section{GEREÇ VE YÖNTEM}

\section{Kimyasallar}

Çalışmada kullanılan, Canavalia ensiformis kaynaklı üreaz (15-50 U/mg katı), Florisil, 3-APTES, glutaraldehit ve diğer kimyasallar Sigma firmasından temin edilmiştir.

\section{Florisil'in modifikasyonu}

Modifiye edilmiş Florisilin hazırlanmasında literatürede daha önce Tükel ve Alptekin ${ }^{13}$ tarafından önerilen yöntem kullanılmıştır. Üreazın desteğe immobilizasyonunda Florisil önce $\mathrm{HNO}_{3}$ ile yıkandı daha sonra 3-APTES ile aktifleştirildi. Florisil'den $10 \mathrm{~g}$ tartılarak üzerine $\% 5$ (w/v)'lik $\mathrm{HNO}_{3}$ çözeltisinden $50 \mathrm{~mL}$ eklendi. Karışım 80$90^{\circ} \mathrm{C}$ 'de 1 saat boyunca karıştırıldı. Daha sonra destek süzülerek saf su ile y1kand1 ve $120^{\circ} \mathrm{C}$ 'de etüvde kurutuldu.

Kurutulmuş destekten $1 \mathrm{~g}$ alınarak üzerine \%4'lük (v/v) asetonda hazırlanan 3-APTES çözeltisinden eklendi ve karışım $45^{\circ} \mathrm{C}$ 'de 24 saat bekletildi. 3APTES ile silanlanan destek saf su ile yıkanarak $115^{\circ} \mathrm{C}$ 'de 1 gece bekletildi. Silanlanmış destekten $1 \mathrm{~g}$ alınarak üzerine pH's1 7,0 olan $50 \mathrm{mM}$ fosfat tamponunda hazırlanmış \%2,5'lik (w/v) glutaraldehit çözeltisinden eklendi ve karışım 2 saat oda sıcaklığında karıştırıldı. Destek saf su ile y1kanarak $60^{\circ} \mathrm{C}$ 'de kurutuldu.

\section{Üreazın immobilizasyonu}

Modifiye edilmiş destekten $1 \mathrm{~g}$ tartılarak üzerine pH's1 7,0 olan $50 \mathrm{mM}$ fosfat tamponunda derișimi 1 $\mathrm{mg} / \mathrm{mL}$ olacak şekilde hazırlanan üreaz çözeltisinden $4 \mathrm{~mL}$ eklendi. Karışım oda sıcaklığında çalkalayıcıda $60 \mathrm{rpm}$ hızla 2 saat karıştırıldı. İmmobilize üreaz süzüldü ve süzüntüde protein kalmayıncaya kadar yıkandı. Süzüntüler protein tayini için biriktirildi. Desteğe bağlanan üreaz miktarının belirlenmesi amaciyla süzüntüde bikinkoninik asit kullanılarak protein tayini yapild $1^{14}$. Başlangıçta immobilizasyon ortamına eklenen protein miktarından toplanan süzüntüde bulunan protein miktarı çıkarılarak 1 gram desteğe bağlanan protein miktarı belirlendi. 


\section{Serbest ve immobilize üreazın aktivitelerinin ölçülmesi}

Serbest ve immobilize üreazın spesifik aktivitesi spektrofotometrik olarak ölçülmüştür ${ }^{15} \cdot 1,0 \times 10^{-2} \mathrm{mg}$ serbest üreaz veya $20 \mathrm{mg}$ immobilize üreaz preparatı pH's1 7,0 olan HEPES tamponu içine $(15 \mathrm{mM}$ üre ve $0,05 \mathrm{mM}$ EDTA içeren) eklenerek $30^{\circ} \mathrm{C}$ 'de $30 \mathrm{dk}$. çalkalayıcılı su banyosunda inkübe edildi. Daha sonra 0,32 $\mathrm{M} \mathrm{H}_{2} \mathrm{SO}_{4}$ çözeltisinden $0,3 \mathrm{~mL}$ ve \%0,3’lük (w/v) $\quad \mathrm{Na}_{2} \mathrm{WO}_{4}$ çözeltisinden $0,3 \mathrm{~mL}$ eklenerek tepkime durduruldu. Nessler reaktifi eklenerek çözeltinin 405 nm'deki absorbans1 ölçüldü. Tepkime sırasında açığa çıkan amonyum miktarını belirlemek için analitik saflıkta $\mathrm{NH}_{4} \mathrm{Cl}$ kullanılarak oluşturulan standart eğri kullanıldı. Üreaz için spesifik aktivite, 1 dakikada $1 \mu \mathrm{mol}$ $\mathrm{NH}_{4}{ }^{+}$u $\mathrm{u}$ açığa çıkaran enzim olarak tanımlandı. Aktivite ölçümleri en az 3 tekrarlı çalışıldı.

\section{Serbest ve immobilize üreazın karakterizasyonu}

Serbest ve immobilize üreaz örneklerinin aktiviteleri farklı pH'larda $(4,5-8,0)$ ve sicaklıklarda $\left(20-70^{\circ} \mathrm{C}\right)$ ölçüldü. Serbest ve immobilize üreaz örneklerinin en yüksek aktivite gösterdikleri ortam $\mathrm{pH}$ 's 1 ve sicaklik belirlendi. Enzimlerin aktivite değerleri bağıl olarak hesaplandi. Serbest ve immobilize üreaz örneklerinin farklı substrat derişimlerinde (1,5-15 $\mathrm{mM}$ üre) belirlenen optimum $\mathrm{pH}$ ve sıcaklık değerlerinde aktiviteleri ölçüldü. Lineweaver - Burk grafiği kullanılarak $K_{\mathrm{m}}$ ve $V_{\max }$ değerleri belirlendi. $K_{\mathrm{m}}$ ve $V_{\max }$ değerleri kullanılarak serbest ve immobilize üreaz için $k_{\text {cat }}$ (geri dönüşüm sayıs1) ve $k_{\text {cat }} / K_{\mathrm{m}}$ (katalitik etkinlik) değerleri hesaplandı. Derişimi $10 \mu \mathrm{g} / \mathrm{mL}$ olan üreaz çözeltisi ve immobilize üreazın kurutulmuş formu oda sicaklığında ve $4^{\circ} \mathrm{C}$ 'de bekletildi ve belirli zaman aralıklarında aktiviteleri ölçülerek depolama kararlılıkları belirlendi. İmmobilize üreazın kesikli tip biyoreaktörde tekrar kullanım kararlılı̆̆1 araştırıldı. Bunun için immobilize üreaz örneğinden $35 \mathrm{mg}$ alınarak çapı 1,3 cm, yüksekliği $5,8 \mathrm{~cm}$ olan reaktöre yerleştirildi. Üzerine derişimi $15 \mathrm{mM}$ olan üre çözeltisinden 1,5 mL eklenerek $30 \mathrm{dk}$. oda sıcaklığında bekletildi. $30 \mathrm{dk}$. sonunda çözelti hızla reaktörden uzaklaştırıldı. Süzüntüye $0,45 \mathrm{~mL} \mathrm{H}_{2} \mathrm{SO}_{4}$ $(0,32 \mathrm{M})$ ve $0,45 \mathrm{~mL} \mathrm{Na} \mathrm{WO}_{4}(\% 0,3$ 'lük (w/v)) çözeltilerinden eklendi. Süzüntüde enzimatik tepkime sırasında açığa çıkan $\mathrm{NH}_{4}{ }^{+}$miktarı belirlendi. Substrat çözeltisinden tekrar reaktöre eklenerek aynı işlemler tekrar edildi. Her bir kullanımda kalan enzim aktivitesi hesaplandi. Böylece kesikli tip biyoreaktör sisteminde immobilize üreaz preparatının tekrar kullanım kararl1lı̆̆ belirlendi.

\section{İstatistiksel analiz}

Serbest ve immobilize üreazın kinetik parametreleri ortalama \pm standart sapma şeklinde verildi.

\section{BULGULAR}

Üreaz modifiye edilmiş Florisil desteğine kovalent olarak bağlanmıştır. Desteğe bağlanan enzim miktarı 3,9 mg/ g destek, enzimin desteğe bağlanma oranı \%97 olarak belirlenmiştir. İmmobilize üreaz örneği için taramalı elektron mikroskobunda alınan görüntüler Şekil 1'de verilmiştir.

Modifiye edilmiş Florisil desteğin immobilizasyondan sonra elde edilen görüntülerinde yüzey morfolojisinin değiştiği, yüzeydeki girinti ve çıkıntıların arttığı görülmüştür.

Serbest ve immobilize üreaz preparatları için farklı pH'da yapılan aktivite ölçümleri sonucunda elde edilen veriler bağıl olarak Şekil 2'de verilmiştir.

Serbest üreaz en fazla aktiviteyi $\mathrm{pH}$ 6,5'de gösterirken, immobilize üreaz $\mathrm{pH}$ 7,0'de göstermiştir. Serbest ve immobilize üreaz preparatları için farklı sıcaklılarda yapılan aktivite ölçümleri sonucunda elde edilen veriler Şekil 3'de verilmiştir.

Serbest üreaz en yüksek aktiviteyi $50^{\circ} \mathrm{C}$ 'de, immobilize üreaz ise $60^{\circ} \mathrm{C}$ 'de göstermiştir.Kinetik parametreler ( $K_{\mathrm{m}}$ ve $\left.V_{\max }\right)$, Lineweaver-Burk grafiği kullanılarak belirlenmiştir. Bu veriler kullanılarak serbest ve immobilize üreaz için $k_{\text {cat }}$ ve $k_{\text {cat }} / K_{\mathrm{m}}$ değerleri hesaplanmıştır. Serbest ve immobilize üreazlara ait kinetik parametreler Tablo 1'de verilmiştir.

İmmobilizasyondan sonra üreazın $K_{\mathrm{m}}$ değeri 2,2 kat artmıştır. İmmobilizasyondan sonra üreazın aktivitesinde anlamlı bir azalma meydana gelmiştir. İmmobilize üreazın katalitik etkinliği serbest üreazın katalitik etkinliğinin $\% 0,1$ ’i kadar olduğu belirlenmiştir. 


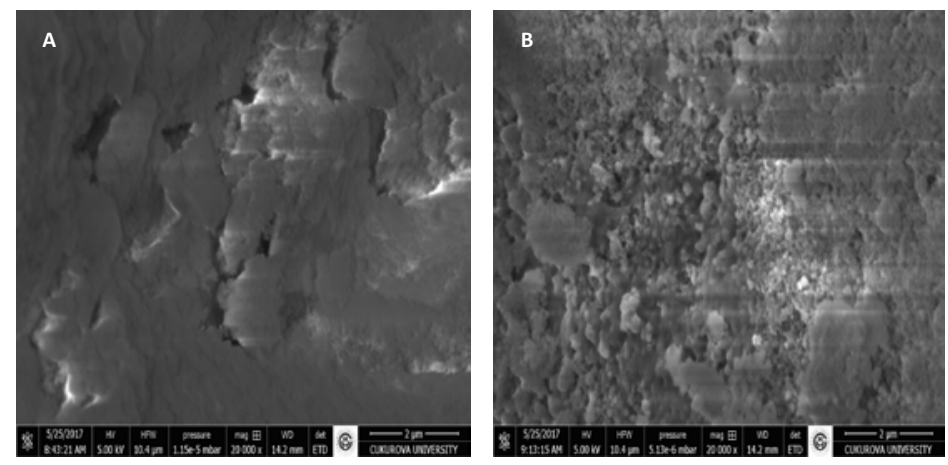

Şekil 1. Taramalı elektron mikroskobu görüntüsü. A. Orijinal Florisil'e ait 20.000 kat büyütülmüş görüntü. B. Üreazın bağlandığı modifiye Florisil'e ait 20.000 kat büyütülmüş görüntü.

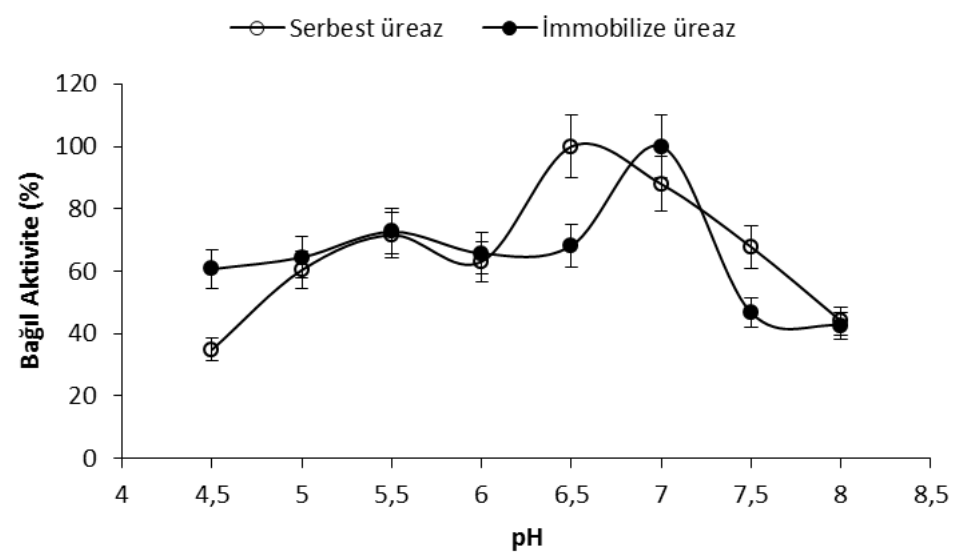

Şekil 2. Serbest ve immobilize üreazın farklı pH'daki tepkime ortamlarında ölçülen aktivite değerlerindeki bağıl değişim.

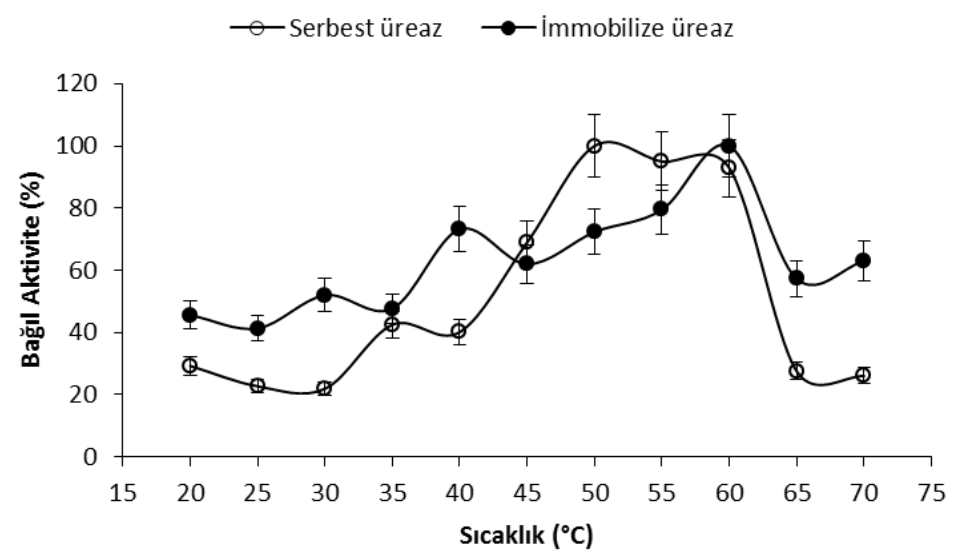

Şekil 3. Serbest ve immobilize üreazın farklı sıcaklılarda aktivite değerlerindeki bağıl değişim. 
Tablo 1. Serbest ve immobilize üreazın kinetik parametreleri.

\begin{tabular}{|l|l|l|}
\hline & Serbest Üreaz & İmmobilize Üreaz \\
\hline$K_{\mathrm{m}}(\mathrm{mM})$ & $2,7 \pm 0,1$ & $5,9 \pm 0,3$ \\
\hline$V_{\max }(\mathrm{U} / \mathrm{mg}$ protein $)$ & $51,5 \pm 2,6$ & $0,09 \pm 0,01$ \\
\hline$k_{\mathrm{cat}}\left(\mathrm{s}^{-1}\right)$ & $68,7 \pm 3,4$ & $0,12 \pm 0,01$ \\
\hline$k_{\mathrm{cat}} / K_{\mathrm{m}}\left(\mathrm{s}^{-1} \mathrm{M}^{-1}\right)$ & $2,5( \pm 0,1) \times 10^{4}$ & $2,0( \pm 0,1) \times 10^{1}$ \\
\hline
\end{tabular}

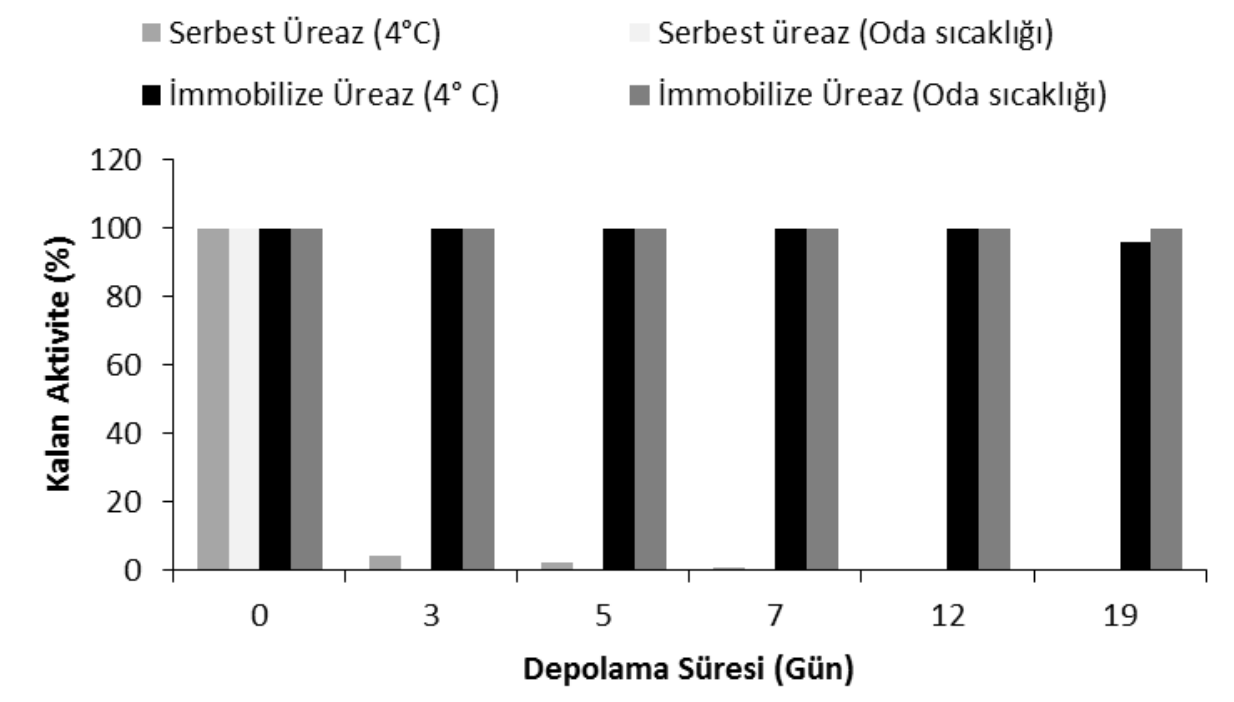

Şekil 4. Serbest ve immobilize üreazın $4^{\circ} \mathrm{C}$ ve oda sıcaklığındaki depolama kararlılıkları.

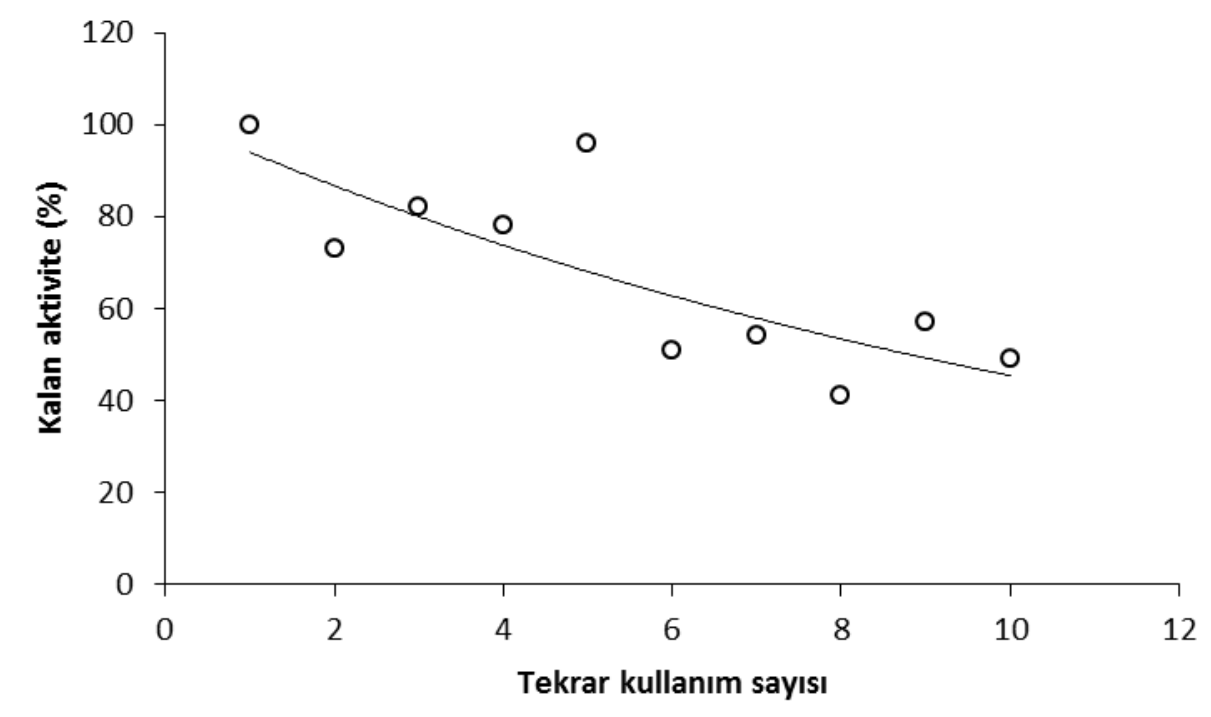

Şekil 5. İmmobilize üreazın kesikli tip biyoreaktörde tekrar kullanım kararlılığı. 
Serbest ve immobilize üreazın depolama kararlılıkları oda sicaklığında ve $4{ }^{\circ} \mathrm{C}$ 'de belirlendi. Serbest ve immobilize üreazın depolama süresine bağlı aktivite değişimi Şekil 4'de verilmiştir. Serbest üreaz hem $4^{\circ} \mathrm{C}^{\prime}$ de hem de oda sicaklığında 5 gün sonunda aktivitesinin tamamını kaybetmiştir. İmmobilize üreaz aynı koşullarda 12 gün sonunda aktivitesini kaybetmezken, 26 günde oda sicaklığında başlangıç aktivitesinin \%64'ünü $4^{\circ} \mathrm{C}^{\prime} \mathrm{de}$ ise \%80'nini korumuştur. İmmobilize üreazın kesikli tip biyoreaktör sisteminde tekrar kullanıma bağlı aktivite değişimi Şekil 5'de gösterilmiştir. İmmobilize üreaz biyoreaktörde 10 kez tekrar kullanıldığında başlangıç aktivitesinin yaklaş1k \%50'sini korumuştur.

\section{TARTIŞMA}

Florisil, 3-APTES ile aktifleştirilerek yüzeyinde serbest $-\mathrm{NH}_{2}$ gruplarının bulunması sağlanmıştır. Daha sonra destek glutaraldehit ile modifiye edilmiştir. Glutaraldehitin bir ucu destekteki amino grupları ile Schiff bazı oluştururken diğer ucu yüzeyde aldehit gruplarının bulunmasını sağlamıştır. Son aşamada enzim modifiye destek ile muamele edildiğinde destekteki aldehit grupları ile enzimde bulunan $-\mathrm{NH}_{2}$ grupları (lizin amino asit artıkları ya da $\mathrm{N}$ ucu) ile Schiff bazı oluşturarak kovalent bağlanmıştır. Amin grubu içeren katı desteğe enzimin glutaraldehit ile bağlanması yaygın olarak kullanılan bir yöntemdir ${ }^{16}$. Desteğin glutaraldehit ile muamelesinden sonra desteğin su ile yrkanarak ortamdaki serbest glutaraldehitin destekten tamamen uzaklaştırılması çok önemlidir. Destekte kalan serbest glutaraldehit immobilizasyon sirasinda üreazın hizla inaktif olmasina neden olmaktadır ${ }^{17}$. Desteğe immobilizasyondan önce uygulanan işlemler $\mathrm{HNO}_{3}$ çözeltisi ile muamele, 3-APTES ile aktifleștirme ve glutaraldehit ile modifikasyon) desteğin yüzeyinde girinti ve çıkıntıların artmasına dolayısıyla yüzey morfolojisinde değişikliğe neden olmuştur. $\mathrm{Bu}$ bulgular desteğin modifikasyon sonunda yüzey alanının artmış olabileceğini göstermektedir. Enzim boyutunun (12 nm) desteğin gözenek boyutundan (6-8 nm) küçük olması nedeni ile üreazın desteğin gözeneklerine girmeden desteğin yüzeyine bağlandığı düşünülmektedir. Alatawi ve arkadaşlar1 $^{18}$ epiklorohidrin ile çapraz bağl1 karboksimetil selüloz destekte yaptıkları modifikasyonlar ile destekteki $-\mathrm{NH}_{2}$ gruplarının miktarını 4-8 mmol/ $g$ destek olduğunu bildirmişlerdir. Destekteki $-\mathrm{NH}_{2}$ miktarı arttıkça bağlanan enzim miktarının arttığını (80-212 mg/ g destek), bununla birlikte immobilize üreazın aktivitesinde azalma olduğunu bildirmişlerdir. İmmobilize üreazın aktivitesi, desteğe bağlanma miktarına, desteğin doğasına ve immobilizasyon yöntemine bağlı olarak çeşitlilik göstermektedir ${ }^{15,19}$.

İmmobilizasyon ile üreazın optimum pH's1 0,5 birim artmıştır. Lizinin $\varepsilon$-amino grubu gibi bazik gruplar üzerinden gerçekleşen kovalent bağlanma sonucu enzim molekülü serbest haline kıyasla daha polianyonik bir yapıya kavuşmakta ve bunun sonucu olarak taşıyıcıya bağlı enzimin optimum pH's1 serbest enziminkine kıyasla bazik bölgeye kayabilmektedir ${ }^{16}$. Literatürde benzer sonuç kumaş yüzeyine glutaraldehit üzerinden kovalent bağlanmış üreaz için bildirilmiştir. Üreazın optimum pH'sının immobilizasyondan sonra 7,0'den 7,5'e yüksseldiği bildirilmiştir.

İmmobilize üreazın optimum sıcaklığ1 immobilizasyondan etkilenmiştir. İmmobilizasyon sonrasında üreazın optimum sicaklığ $10^{\circ} \mathrm{C}$ artmıştır. İmmobilize üreazın serbest üreaza göre yüksek sicaklıklarda daha yüksek aktivite göstermesi, immobilize üreazın termal kararlılı̆̆ının daha yüksek olmasından kaynaklanabilir. $\mathrm{Bu}$ durum, üreazın desteğe kovalent bağlanması sırasında aynı anda çok sayıda kovalent bağ yapmasından kaynaklanabilir. Çoklu bağlanma, sıcaklık artışı ile enzimdeki konformasyonel değişimleri sınırlandırır ${ }^{18}$. Yeon ve Lueptow ${ }^{20}$, kumaşa kovalent bağlanmış immobilize üreazın optimum sicaklığının $55^{\circ} \mathrm{C}$ olduğunu, immobilizasyondan sonra optimum sicalıklığın 10 ${ }^{\circ} \mathrm{C}$ arttı̆̆ bildirmişlerdir.

$\mathrm{Bu}$ çalışmada, immobilizasyon sonucunda üreazın $K_{\mathrm{m}}$ değeri yaklaşık 2,2 kat artmıştır. Literatürde immobilizasyon sonrasında üreazın $K_{\mathrm{m}}$ değerinin $\operatorname{arttığın1~}{ }^{18,20-24}$ ve azaldığını ${ }^{18,20,21,24}$ bildiren çalışmalar bulunmaktadır. İmmobilize üreazın kinetik parametrelerinin serbest üreazdan farklilik göstermesinin nedenleri, immobilizasyon ile enzimin üç boyutlu yapısında meydana gelen değişimler, sterik etkiler, mikroçevre ve difüzyon sınırlamaları olabilir ${ }^{16,17,25}$. Literatürde üreazın immobilizasyondan sonra $V_{\max }$ değerinin \%30- \%90 oranında azaldığını bildiren araştırma bulguları rapor edilmiştir ${ }^{16,18,20,24-}$ 27.

Depolama kararlilı̆gı uzun süre saklama durumunda enzimin aktivite kaybının bir ölçüsüdür. Serbest üreaz 5 gün sonunda hem oda sicaklığında hem de $4^{\circ} \mathrm{C}$ 'de başlangıç aktivitesinin tamamını kaybetmiştir. İmmobilize üreaz ise her iki sıcaklikta 12 gün 
sonunda aktivitesinin tamamını korumuştur. Yeon ve Lueptow $^{20}$, kumaşa immobilize edilen üreazın $4^{\circ} \mathrm{C}$ 'de 98 gün sonunda başlangiç aktivitesinin $\% 50$ 'sini kaybettiğini bildirmişlerdir. Alatawi ve arkadaşlar1 ${ }^{18}$, karboksimetil selüloza immobilize edilen üreazın oda sicaklığında 1 hafta sonunda başlangıç aktivitesinin \%30'unu kaybettiğini, serbest üreazın ise başlangıç aktivitesinin \%80'nini kaybettiğini bildirmişlerdir.

İmmobilize enzimlerin etkin kullanımları için tekrar kullanılabilirlikleri en önemli faktörlerden biridir. ${ }^{19}$ Bu çalışmada, kesikli tip biyoreaktörde 10 kullanım sonunda immobilize üreaz başlangı̧ aktivitesinin $\% 50$ 'sini korumuştur. Alatawi ve arkadaşları ${ }^{18}$, epiklorohidrin ile çapraz bağlı karboksimetil selüloza kovalent immobilize edilmiş üreazın kesikli reaktörde 10 kullanım sonunda başlangıç aktivitesinin \%88'ini koruduğunu bildirmişlerdir. Başka bir çalışmada, ipek fibroin üzerine kovalent immobilize edilmiş üreazın 7 kullanımdan sonra aktivitesinin değişmediği bildirilmiştir ${ }^{19}$. Doğaç ve Teke ${ }^{21}$, kitosan kaplı alginat nikel-ferrit boncuğa immobilize edilmiş üreazın $18 \mathrm{kez}$ kullanımdan sonra başlangıç aktivitesinin yarısının kaldığını bildirilmişlerdir.

Sonuç olarak, modifiye edilmiş Florisil desteğe üreaz yüksek oranda (\%97) kovalent olarak immobilize edilmiştir. İmmobilizasyondan sonra üreazın optimum $\mathrm{pH}$ ve sıcaklık değerleri değişmiş, aktivitesi azalmıştır. Ancak, immobilize üreazın depolama kararlilığ1 hem $4^{\circ} C^{\prime}$ de hem de oda sicaklığında serbest üreazdan daha yüksek bulunmuştur. Ayrıca immobilize üreazın kesikli tip biyoreaktör sisteminde 10 kullanım sonunda başlangıç aktivitesinin \%50'sini koruması, immobilize üreazın kesikli tip biyoreaktörde kullanım potansiyelinin yüksek olduğunu göstermektedir.

Yazar Katkıları: Calıșma konsepti/Tasarımı: ÖA; Veri toplama: ÖA; Veri analizi ve yorumlama: ÖA; Yazı taslağı: ÖA; İçeriğin eleştirel incelenmesi: ÖA; Son onay ve sorumluluk: ÖA; Teknik ve malzeme desteği: ÖA; Süpervizyon: ÖA; Fon sağlama (mevcut ise): yok. Hakem Değerlendirmesi: Dış bağımsız.

Çıkar Çatışması: Yazarlar çıar çatıșmasıı bevan etmemişlerdir. Finansal Destek: Yazarlar finansal destek beyan etmemişlerdir. Author Contributions: Concept/Design : ÖA; Data acquisition: ÖA; Data analysis and interpretation: ÖA; Drafting manuscript: ÖA; Critical revision of manuscript: ÖA; Final approval and accountability: ÖA; Technical or material support: ÖA; Supervision: ÖA; Securing funding (if available): $\mathrm{n} / \mathrm{a}$.

Peer-review: Externally peer-reviewed.

Conflict of Interest: Authors declared no conflict of interest. Financial Disclosure: Authors declared no financial support

\section{KAYNAKLAR}

1. Krajewska B, Ciurli S. Jack bean (Canavalia ensiformis) urease. Probing acid-base groups of the active site by pH variation. Plant Physiol Biochem. 2005;43:651-8.

2. Blakely RL, Zerner B. Jack Bean Urease: The First Nickel Enzyme. J Mol Catal. 1984;23:263-92.

3. Takishima K, Suga T, Mamiya G. The structure of jack bean urease. The complete amino acid sequence, limited proteolysis and reactive cysteine residues. Eur J Biochem. 1988;175:151-65.

4. Cao L, Schmid RD. Carrier-bound Immobilized Enzymes: Principles, Application and Design. WileyVCH Verlag GmbH \& Co. KGaA. 2006.

5. Wang L, Wang S, Deng X, Zhang Y, Xiong C. Development of coconut shell activated carbontethered urease for degradation of urea in a packed bed. ACS Sustainable Chem Eng. 2014;2:433-9.

6. Zhou J, Cao J, Huan W, Huang L, Wang Y, Zhang S, Yuan Y, Huaa D. Preparation and property of urease immobilization with cationic poly(4-vinylpyridine) functionalized colloidal particles. Chem Biochem Eng Q. 2013;27:431-7.

7. Uygun M, Akduman B, Akgöl S, Denizli A. A new metal-chelated cryogel for reversible immobilization of urease. Appl Biochem Biotechnol. 2013;170:181526

8. Ispirli Doğaç Y, Deveci I, Teke M, Mercimek B. $\mathrm{TiO}_{2}$ beads and $\mathrm{TiO}_{2}$-chitosan beads for urease immobilization. Mater Sci Eng C Mater Biol Appl. 2014;42:429-35.

9. D'Souza SF, Kumar J, Jha SK, Kubal BS. Immobilization of the urease on eggshell membrane and its application in biosensor. Mater Sci Eng C Mater Biol Appl. 2013;33:850-4.

10. Yücebilgiç G, Güleşci N, Yıldırım D. Immobilization and characterization of urease onto different spacer arms attached magnetic nanoparticles. New Biotechn. 2016;33:1-213.

11. Garg S, De A, Mozumdar S. pH-dependent immobilization of urease on glutathione-capped gold nanoparticles. J Biomed Mater Res A. 2015;103:1771-83.

12. $\mathrm{Lv} \mathrm{M}, \mathrm{Ma} \mathrm{X}$, Anderson DP, Chang PR. Immobilization of urease onto cellulose spheres for the selective removal of urea. Cellulose. 2018;25:233-43.

13. Tükel SS, Alptekin Ö. Immobilization and kinetics of catalase onto magnesium silicate. Process Biochem. 2004;39:2149-25.

14. Smith P K, Krohn R.I, Hermanson GT, Mallia AK, Gartner F H, Provenzano M D, Fujimoto EK, Goeke N M, Olson BJ, Klenk DC. Measurement of protein using bicinchoninic acid. Anal Biochem. 1985;150:76-85.

15. Rao MS, Chellapandian M, Krishnan MRV. Immobilization of urease on gelatin - poly (HEMA) copolymer preparation and 
characterization. Bioprocess Eng. 1995;13:211-4.

16. Wiseman Alan. Handbook of Enzyme Biotechnology. 2nd Edit., John Wiley \& Sons, Chichester, England, 1985.

17. Chen JP, Chiu SH. Preparation and characterization of urease immobilized onto porous chitosan beads for urea hydrolysis. Bioprocess Eng. 1999;21:323-30.

18. Alatawi FS, Monier M, Elsayed NH. Amino functionalization of carboxymethyl cellulose for efficient immobilization of urease. Int $J$ Biol Macromol. 2018;114:1018-25.

19. Moon BM, Choi MJ, Sultan MT, Yang JW, Ju HW, Lee JM et al. Novel fabrication method of the peritoneal dialysis filter using silk fibroin with urease fixation system. J Biomed Mater Res B Appl Biomater. 2017;105:2136-44.

20. Yeon KH, Lueptow RM. Urease immobilization on an ion-exchange textile for urea hydrolysis. J Chem Technol Biotechnol. 2006;81:940-50.

21. Doğaç YI, Teke M. Synthesis and characterisation of biocompatible polymer-conjugated magnetic beads for enhancement stability of urease. Appl Biochem Biotechnol. 2016;179:94-110.

22. Pozniak, G, Krajewska B, Trochimczuk W. Urease immobilized on modified polysulphone membrane: preparation and properties. Biomater. 1995;16:12934.

23. Somtürk B, Yılmaz I, Altınkaynak C, Karatepe A, Özdemir N, Ocsoy I. Synthesis of urease hybrid nanoflowers and their enhanced catalytic properties. Enzyme Microb Technol. 2016;86:134-42.

24. Maia MDMD, de Vasconcelos EA, de Mascena Diniz PFC, da Costa Maciel J, Cajueiro KRR, da Silva MDPC, et al. Immobilization of urease on vapour phase stain etched porous silicon. Process Biochem. 2007;42:429-33.

25. Rogalski J, Szczodrak J, Pleszczyńsk M, Fiedurek J. Immobilisation and kinetics of Penicillium notatum dextranase on controlled porous glass. J Mole Cataly B Enzym. 1997;3:271-83.

26. Kumar, Sandeep; Kansal, Ajay; Kayastha, Arvind M; Immobilization of jack bean (Canavalia ensiformis) urease on gelatin and its characterization. Oriental Pharmacy and Experimental Medicine. 2005;5:43-7.

27. Bayramoğlu G, Altınok H, Bulut A, Denizli A, Arıca MY. Preparation and application of spacer-armattached poly(hydroxyethyl methacrylate-co-glycidyl methacrylate) films for urease immobilisation. Reac Func Polym. 2003;56:111-21. 